REPORTS OF MORPHOLOGY
Official Journal of the Scientific Society of Anatomists,
Histologists, Embryologists and Topographic Anatomists
of Ukraine
journal homepage: https://morphology-journal.com

\title{
Fractal analysis as a method of morphometric study of linear anatomical objects: modified Caliper method
}

Maryenko N.I., Stepanenko O.Yu.

Kharkiv National Medical University, Kharkiv, Ukraine

\section{ARTICLE INFO}

Received: 20 August 2021

Accepted: 17 September 2021

UDC: $611: 57.086: 517: 530.191$

CORRESPONDING AUTHOR

e-mail: dmaryenko.n@gmail.com

Maryenko N.I.

\section{CONFLICT OF INTEREST}

The authors have no conflicts of interest to declare.

\section{FUNDING}

Not applicable.
The purpose of the study was to develop an original modification of the Caliper method of image fractal analysis to determine the fractal dimension of linear anatomical objects. To develop the method, the linear contour of the outer surface of the cerebral cortex was chosen as the object of study. Magnetic resonance brain images in coronal projection were used. The original modification of the Caliper method includes image analysis using Adobe Photoshop CS5 software or its analogues. The linear contour of the studied object is selected, followed by stepwise smoothing of the contour with different smoothing radius. At the 1st stage of fractal analysis smoothing is not applied, at the 2nd stage the smoothing radius is 2 pixels, the $3 r d-4$ pixels, the 4 th - 8 pixels, the 5 th -16 pixels. At each stage, the contour length in pixels is measured $(P)$. The size of the fractal measurement unit $(G)$ at the 1 st stage of fractal analysis is 1 pixel, the 2nd stage - 2 pixels, the $3 r d$ stage - 4 pixels, the 4 th stage - 8 pixels, the 5th stage - 16 pixels. The contour smoothing radius, the size of the fractal measurement units and the number of stages of fractal analysis can be changed depending on the characteristics of the studied structure, size, scale and image resolution. Based on the values of the perimeter and the size of the fractal measurement units, the number of fractal measurement units covering the studied object $(N)$ is calculated: $N=P / G$. The fractal dimension value is calculated based on the $N$ and $G$ values. The modification of the Caliper method described in this paper is automatized and does not require much time required for manual calculation. In addition, compared to the classic Caliper method, this modification is more accurate because the measurement is performed automatically. The main limitation of the developed modification is the ability to determine the fractal dimension of only closed contours of studied structures or closed linear structures, because this method involves determining the length of the closed perimeter of the selected image area. The modified Caliper method of image fractal analysis described in this paper can be used in morphology and other fields of medicine for fractal analysis of linear objects: external and internal linear contours of different anatomical structures (cerebellum, cerebral hemispheres) and pathological foci (tumors, foci of necrosis, fibrosis, etc.).

Keywords: fractal analysis, fractal dimension, morphometry, Caliper method, Richardson's method.

\section{Introduction}

Fractal analysis is a method of mathematical analysis that in recent decades is increasingly used as a morphometric method in morphology and in medicine in general. Fractal analysis involves determining the fractal dimension, which is an indicator of the complexity of the spatial configuration and the degree of filling of space with a particular object. Among the anatomical structures that can be visualized on medical images, there are often linear objects - linear contours of various anatomical structures and formations (eg, outer linear contour of the cerebral cortex, outer contour of pathological foci, inner contour of hollow organs, etc.) and linear anatomical structures (membranes, vessels, nerves, fibers, etc.). Fractal analysis can be used for complex morphometric study of such objects.

For fractal analysis in medicine, various methods are used - box counting $[1,8,9,16,18,21]$, pixel dilatation [12, 15], Caliper method [11, 17, 19, 22] and others [3, 4, 6, 7]. Different methods of fractal analysis can take into account 


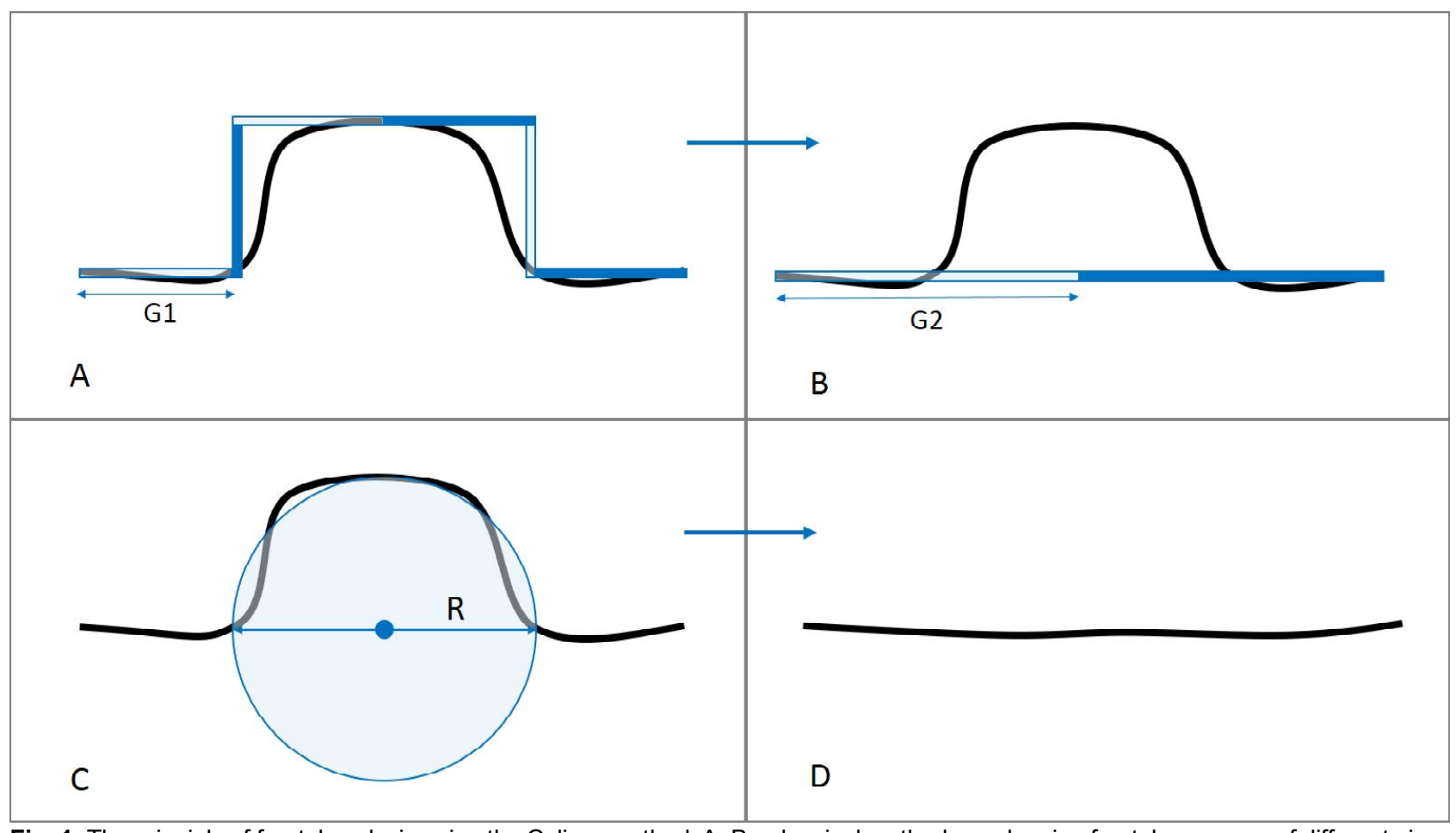

Fig. 1. The principle of fractal analysis using the Caliper method. A, B - classical method, overlapping fractal measures of different sizes $(G 1, G 2)$. C, D - contour modification by smoothing, used in the author's modification of the Caliper method: from a contour containing bends $(A)$, bends with a radius equal to or less than $R$ are removed - the specified value of the smoothing radius (D).

one linear size of the studied objects (length), two linear dimensions (length and width) or three linear dimensions (length, width and height). Linear objects have one linear dimension, namely length, so for their fractal analysis it is advisable to use fractal analysis methods that take into account only one linear dimension. This method of fractal analysis is the Caliper method [13].

The Caliper method also has the following names: Richardson's method, perimeter stepping method, ruler method, divider dimension, compass dimension, yard stick method [6, 7, 13]. Historically, the Caliper method was one of the first methods of fractal analysis. In 1951, the English mathematician Lewis Fry Richardson, while studying the relationship between the length of a border and the number of conflicts between neighboring states, described the paradox of the coastline, which was later called the Richardson Effect. Contradictory data were obtained in determining the length of state borders and the length of the coastline. A compass was used to measure the length of the shoreline: first, a segment of a certain length was measured, which was recorded in a compass, and then the length of the contour was measured step by step on a map (similar to how distances are measured with a surveyor). The length of the shoreline $(L)$ was determined by the number of segments $(N)$ multiplied by their length $(G)$ : $\mathrm{L}=\mathrm{N} \times \mathrm{G}$. L. Richardson noticed that when using segments of different lengths, the total length of the shoreline differed: the smaller (shorter) were the segments used for measurement, the greater the total length of the shoreline. Richardson initially assumed that when using even shorter segments, the length of the shoreline would reach a certain fixed length and later cease to change as the measure decreased, but it turned out that when the length of the segment used for measurement approaches zero, the length of the shoreline goes to infinity. With this in mind, Richardson based on empirical data suggested that the length of the shoreline contour $(L)$ and the size of measure $(G)$ are related by the equation $L(G)=M G^{(1-D)}$, where $M$ is the calculated constant and $D$ (dimension) - a certain quantity that quantifies the dependence of the size of the measure and the measured object and is called dimension. This value ranged from 1 to 2 and corresponded to the metric dimension of the shoreline $[5,14,20]$.

Benoit Mandelbrot later took up the issue, publishing in 1967 "How Long Is the Coast of Britain? Statistical SelfSimilarity and Fractional Dimension" [14], which examines the mathematical aspects of self-similar curves. In this paper, Mandelbrot analyzed the regularities of the organization of self-similar mathematical curves (which are essentially linear mathematical fractals) and determined how the metric dimension of such curves is calculated. The approximation of the length of the self-similar line ( $L$ ) corresponded to $G^{(1-D)}$, where $G$ is the length of the segment used to measure the length, and $D$ is the metric dimension. The metric dimension of such self-similar objects can have not only integer but also fractional values, so it was called fractional dimension (FD) [5, 13, 14, 20].

The classic Caliper method conducted as follows. A linear object is covered by a broken line consisting of linear segments that have a certain fixed length $\left(G_{1}=1\right)$, and count 
$\mathrm{N}_{1}$ - the number of such segments that can be completely placed on this linear object (Fig. 1, A, B). This linear segment is called a fractal measurement unit. The length of the segments is halved and $\mathrm{N}_{2}$ is counted - the number of segments of length $G_{2}=1 / 2$ that can be placed on this object. Then this procedure is repeated several times, iteratively reducing the length of the segments by half $\left(G_{3}=1 / 4, G_{4}=1 /\right.$ $8, G_{5}=1 / 16$, etc.) and at each stage count the number of segments with the appropriate length (respectively N3, N4, $\mathrm{N} 5$ and so on). Then, taking into account the values of $\mathrm{G}$ and $\mathrm{N}$, the fractal dimension (FD) is calculated. For the classical Caliper method, measurements with a caliper (or compass, surveyor, ruler, etc. - depending on the field of use, scale and characteristics of the object) are most often used, which determines the name of the method $[6,7,13]$.

However, the Caliper method in the classic version and known modifications is routine and, due to manual calculation, is not accurate enough to use it as a morphometric method in medicine for diagnostic purposes. Therefore, the search for a fractal analysis method that would be an automated and more accurate analogue of the classical Caliper method prompted the authors to develop their own modification of the fractal analysis of linear objects.

The purpose of the study is to develop an original modification of the Caliper method to determine the fractal dimension of linear anatomical objects.

\section{Materials and methods}

The study was conducted in compliance with the basic bioethical provisions of the Council of Europe Convention on Human Rights and Biomedicine (04.04.1997), the Helsinki Declaration of the World Medical Association on ethical principles of scientific medical research with human participation (1964-2008), and the Ministry of Health of Ukraine № 690 dated September 23, 2009. The conclusion of the Ethics and Bioethics Commission of Kharkiv National Medical University confirms that the study was conducted in compliance with human rights in accordance with current legislation in Ukraine, meets international ethical requirements and does not violate ethical norms in science and standards of biomedical research (Minutes of the meeting of the Commission on Ethics and Bioethics of KhNMU № 10 dated November 7, 2018).

In order to develop our own modification of the fractal analysis technique using the Caliper method, we chose the outer linear contour of the cerebral cortex as the object of study. First, the linear contour of the cortex has fractal properties and can be considered as a natural linear fractal [10]. Secondly, the study of this structure is of great clinical importance, as it allows to quantify the degree of complexity of the spatial configuration of the surface of the cerebral cortex, which in the future can be used for diagnostic purposes [8, 9].

Magnetic resonance imaging of the brain in coronal

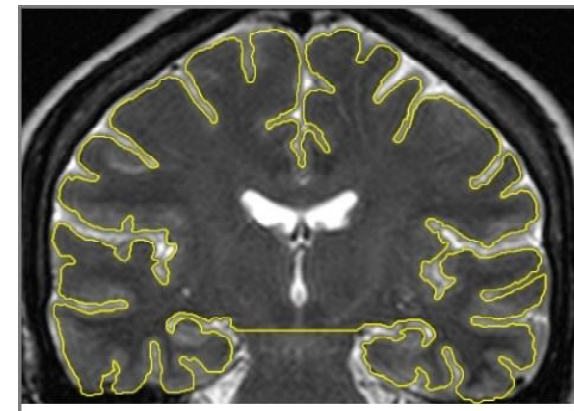

A

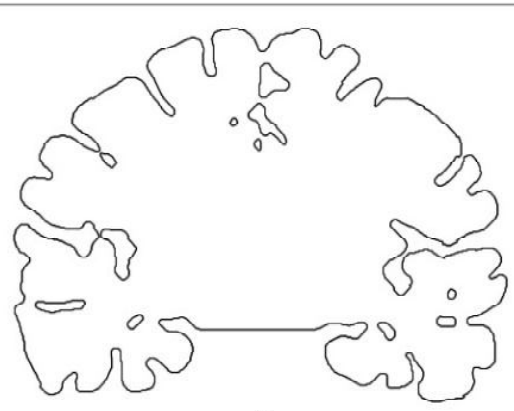

D

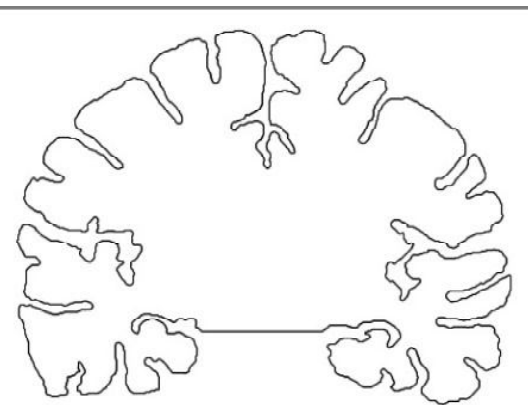

B

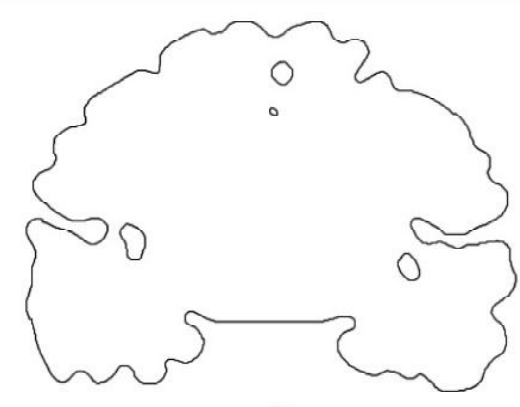

E

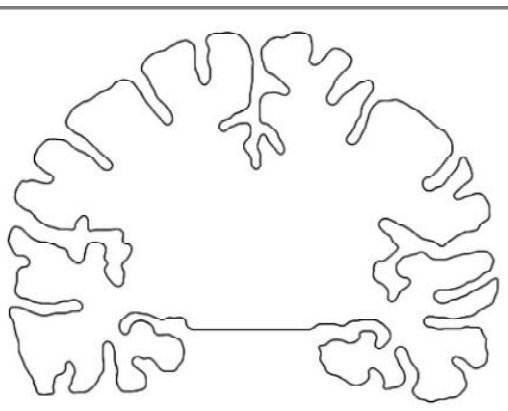

C

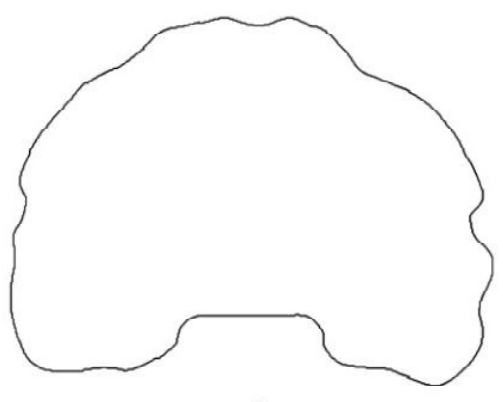

$\mathrm{F}$

Fig. 2. Method of fractal analysis using the author's modification of the Caliper method. A- the original image (magnetic resonance imaging of the brain in the coronal projection), the stroke of the studied contour with a yellow line used. B-F - stages of fractal analysis: B - 1st stage of fractal analysis, contour smoothing not applied, C - 2nd stage, contour smoothing radius 2 pixels, D - 3rd stage, contour smoothing radius 4 pixels, $\mathrm{E}-4$ th stage, radius of smoothing of a contour of 8 pixels, $F$ - 5 th stage, radius of smoothing of a contour of 16 pixels. 
projection, obtained with the help of magnetic resonance imaging with a value of magnetic induction of $1.5 \mathrm{~T}$, was used to develop our own method (Fig. 2). Digital T1 and T2 weighted images of magnetic resonance (MR) tomograms with a resolution of 72 pixels per inch were used (the most common value of resolution for digital MR tomograms).

Image analysis was performed using the graphic editor Adobe Photoshop CS5.

\section{Results}

The technique is performed as follows. Image analysis is performed using an Adobe Photoshop CS5 graphics editor (or other graphics editor with similar parameters). Using the "selection tool", select the area of the digital image that corresponds to the area delineated by a specific linear object - the outer or inner contour of the anatomical structure or formation or the linear anatomical structure as a whole (membrane, vessel wall in cross section, etc.). In this case, the contour of the area of selection should coincide with the studied linear object (in this case - the outer linear contour of the pial surface of the cortex of the cerebral hemispheres). Selection is performed using visual inspection and manual correction (if necessary) (Fig. 2).

Next, you need to measure the length of a linear object using fractal measurement units - linear segments of a certain length. If you use the classic Caliper method, a linear object is covered by a broken line consisting of segments of a certain fixed length; then the number of these segments is counted. In contrast to the classical method, this modification performs an automated calculation of the number of fractal measures placed on the linear contour of the selected area. First, use the "analysis" tool of the Adobe Photoshop CS5 graphics editor to measure the length of the perimeter of the selected area (contour length) in pixels $(P)$. Then determine the size of the fractal measure $(G)$ (size of fractal measurement unit $(G)$ ) - the length in pixels of the segments covering the linear object. Based on these data, calculate $\mathrm{N}$ - the number of fractal measures covering the object under study: $\mathrm{N}=\mathrm{P} / \mathrm{G}$. The calculation data are entered in the table (Table 1).

In the first stage of fractal analysis, the smallest possible

Table 1. Fractal analysis of a linear object. Counting data at 1-5 stages of fractal analysis.

\begin{tabular}{|c|c|c|c|c|}
\hline $\begin{array}{c}\text { Stage of } \\
\text { fractal } \\
\text { analysis }\end{array}$ & $\begin{array}{c}\mathrm{G} \text { - fractal } \\
\text { measure, } \\
\text { absolute } \\
\text { values } \\
\text { (number of } \\
\text { pixels) }\end{array}$ & $\begin{array}{c}\mathrm{P} \text { - length of } \\
\text { linear } \\
\text { contour } \\
\text { (perimeter) } \\
\text { (number of } \\
\text { pixels) }\end{array}$ & $\begin{array}{c}\mathrm{N} \text { - the number } \\
\text { of fractal } \\
\text { measures of } \\
\text { length } \mathrm{L} \text {, placed } \\
\text { on the perimeter } \\
\text { of the contour } \\
\text { (N=P/G) }\end{array}$ & $\begin{array}{c}\mathrm{R} \text { - contour } \\
\text { smoothing } \\
\text { radius } \\
\text { (number of } \\
\text { pixels) }\end{array}$ \\
\hline 1 & 1 & 3867 & 3867 & - \\
\hline 2 & 2 & 3646 & 1823 & 2 \\
\hline 3 & 4 & 2505 & 626.25 & 4 \\
\hline 4 & 8 & 1739 & 217.375 & 8 \\
\hline 5 & 16 & 1253 & 78.3125 & 16 \\
\hline
\end{tabular}

value of $G$ is used. The length of the shortest linear segments of a broken line, which can cover a linear object in a digital image and measure its length (similar to the classic Caliper method), is 1 pixel. In subsequent calculations, 1 pixel can be considered the smallest possible size of the fractal measure G. On the MR image of the brain used as an example of the calculation (Fig. 2), the length of the contour $\left(P_{1}\right)$ was 3867 pixels (Table 1). Since $G_{1}$ is equal to 1 pixel, the number of fractal measures covering the object under study in the first stage of fractal analysis $\left(N_{1}\right)$ is: $N_{1}=P_{1} / G_{1}=3867$ pixels $/ 1$ pixel= 3867 .

After that it is necessary to double the size of the fractal measure $G$, in the second stage of fractal analysis $G$ should be equal to 2 pixels, in the third -4 , fourth -8 , fifth -16 . In order to automatically increase the size of the fractal measure, a gradual modification of the contour: using the "selection-modification-smoothing tool", the Adobe Photoshop CS5 graphics editor smoothes a contour with different smoothing radius $(R)$ values. This allows you to automatically replicate the algorithm of the classic Caliper method, which involves the use of linear segments that cover a linear fractal object in the form of a broken line.

If a linear object has bends, then depending on the radius of these bends, the linear fractal segments will cover them differently. If the bends of a linear object have a radius greater than the length of the linear fractal segment, the segments will be placed on the curved sections of the linear object, covering this bend with a broken line (Fig. 1A). But fractal linear segments cannot repeat with a broken line bends that have a radius smaller than the length of this segment (Fig. 1B). Therefore, in such areas fractal segments are placed without repeating the small curves of the contour - "smoothing" the contour.

Adobe Photoshop "smoothing tool" modifies a selected area of an image as follows: add or subtract selection areas that lie on the outline and have a radius smaller than the anti-aliasing radius to the selected area. In this case, all bends of the linear contour with a radius less than or equal to the specified value of the smoothing radius are removed from the contour, replacing the smooth line ("smoothed") (Fig. 1C, 1D). For example, if the line has bends with a radius of less than 2 pixels, when smoothing with a radius of 2 pixels, they will be replaced by linear segments that do not have these bends. Thus, automated contour smoothing removes small curves from the line and allows you to measure the length of the contour in the same way as using the classic Caliper method, but more accurately and automatically.

At the first stage of fractal analysis, the length of the fractal segment was 1 pixel, which allowed to fully cover all the smallest curves of the linear contour, so the smoothing of the contour was not necessary. But in order to increase the length of the linear fractal segment, in the second or fifth stages of fractal analysis, a gradual smoothing of the contour is performed.

In the second stage of fractal analysis, the contour 
Table 2. Fractal analysis of a linear object. Data used to calculate fractal dimension.

\begin{tabular}{|c|c|c|c|c|c|c|}
\hline \multirow{2}{*}{$\begin{array}{l}\text { Stage of } \\
\text { fractal } \\
\text { analysis }\end{array}$} & \multicolumn{4}{|c|}{ G - fractal measure } & \multicolumn{2}{|l|}{$\mathrm{N}$} \\
\hline & $\begin{array}{l}\text { G - absolute values } \\
\text { (number of pixels) }\end{array}$ & $\begin{array}{c}g-\text { fractional } \\
\text { values }\end{array}$ & $1 / g$ & $\ln (1 / g)$ & $\begin{array}{l}\mathrm{N} \text { - number of fractal measures of length } \mathrm{L} \\
\text { placed on the perimeter of the contour }(N=P / G)\end{array}$ & $\ln (\mathrm{N})$ \\
\hline 1 & 1 & $1 / 16$ & 16 & 2.77 & 3867 & 8.26 \\
\hline 2 & 2 & $1 / 8$ & 8 & 2.08 & 1823 & 7.51 \\
\hline 3 & 4 & $1 / 4$ & 4 & 1.39 & 626.25 & 6.44 \\
\hline 4 & 8 & $1 / 2$ & 2 & 0.69 & 217.375 & 5.38 \\
\hline 5 & 16 & 1 & 1 & 0.00 & 78.3125 & 4.36 \\
\hline
\end{tabular}

smoothing radius is 2 pixels. Accordingly, $G_{2}$ is equal to 2 pixels. Then re-measure the length of the contour in pixels $\left(P_{2}\right)$. The length of the contour in Fig. 2 at this stage was 3646 pixels. Then determine the number of fractal measures $G$ that cover the object under study. This amount for the image in Fig. 2 is: $N_{2}=P_{2} / G_{2}=3646$ pixels $/ 2$ pixels $=1823$.

In the third stage of fractal analysis, the contour smoothing is repeated, but with a smoothing radius of 4 pixels. Therefore, $G_{3}$ is equal to 4 pixels. After smoothing, re-measure the length of the contour $\left(\mathrm{P}_{3}\right)$. The length of the contour in Fig. 2 at this stage was 2505 pixels. Therefore, the number of fractal measures covering the object under study is $N_{3}=P_{3} / G_{3}=2505$ pixels $/ 4$ pixels $=626,25$.

In the fourth and fifth stages of fractal analysis, the contour is smoothed with radii of 8 and 16 pixels, respectively. $G_{4}$ and $G_{5}$ are 8 and 16 pixels respectively. After each smoothing, measure the length of the contour in pixels $\left(\mathrm{P}_{4}, \mathrm{P}_{5}\right)$. N4 and $\mathrm{N} 5$ are calculated similarly to the previous stages of fractal analysis and entered in the table (Table 1).

After the fifth modification of the contour by smoothing it, an almost smooth linear contour is obtained (Fig. 2).

To calculate the fractal dimension, you also need to determine the fractional values of the fractal measure $G$. If the largest value of $G\left(G_{5}\right)$ is 16 pixels, the fractional value of $g$ (measure of iterative division $G$ ) is at the first stage of fractal analysis $g_{1}=1 / 16$, the second $-g_{2}=1 / 8$, the third $g_{3}=1 / 4$, the fourth $-g_{4}=1 / 2$, the fifth $-g 5=1$ (Table 2 ).

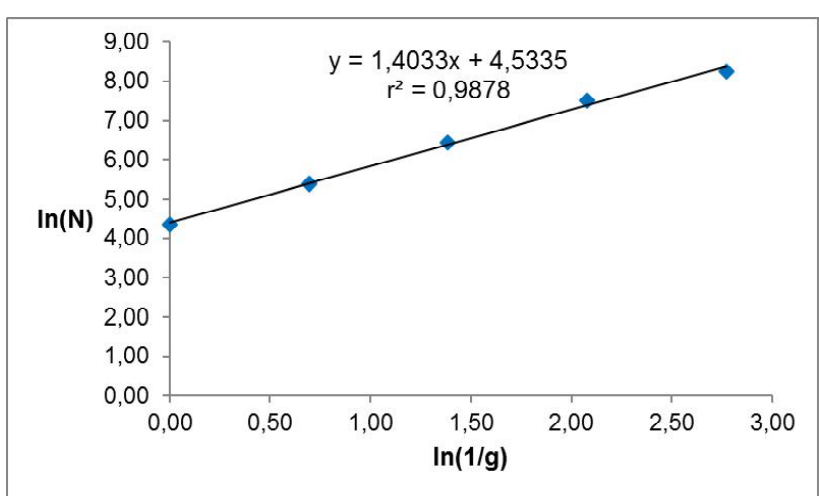

Fig. 3. Graph of linear dependence when calculating the fractal dimension of the linear contour of the cortex of the cerebral hemispheres.
Thus, if when using the classical Caliper method, the value of $g$ in the first stage is the largest and in the following stages it decreases again (often divided in half), then this modification uses the inverse iterative change of fractal measure: in the first stage of fractal analysis measure $\mathrm{g}$ is the smallest, and in the second or fifth stages this measure is iteratively doubled.

The contour smoothing radius, the size of the fractal measure and the number of stages of fractal analysis can be changed depending on the characteristics of the studied structure, size, scale and image resolution.

To determine the fractal dimension, the natural logarithms of two numbers are calculated: $\mathrm{N}$ and numbers inverse to the value of $g(1 / g)$ (Table 2$)$. Then the linear dependence of $\ln (N)$ on $\ln (1 / \mathrm{g})$ is determined by the linear regression equation. The fractal dimension is equal to the slope of the direct regression relative to the abscissa axis (Fig. 3).

The linear regression equation in Fig. 3 has the form $y=1.4033 x+4.5335$, thus, the fractal dimension of the outer linear contour of the cortex of the cerebral hemispheres (Fig. 2) is 1.4033 .

\section{Discussion}

Currently, the Caliper method is used to determine the fractal dimension of the linear contour of various objects in geology [2], and this method is sometimes used in medicine [11, 17, 19, 22]. In studies [17, 22], the authors developed an original modification of this method, adapted for the study of tree-like structures - dendritic neurons tree (in the classical version, the Caliper method is used to study contours). To do this, the researchers divided the dendritic tree into linear continuous and unbranched segments. Each of the linear segments was then measured with a compass, and the fractal dimension was calculated from the total length of all linear segments that were part of the branched dendritic tree.

The original modification of the Caliper method described in this paper has its advantages when used as a morphometric method for the study of linear objects compared to the classical Caliper method. The classic method involves overlapping segments of different lengths on a linear object. Most often this is done manually with a caliper (compass, surveyor, ruler, etc.). However, this 
measurement is routine and inaccurate, as the way the segments are superimposed on the contour can be influenced by subjective factors: the segments can be superimposed on the contour in different ways, which may cause differences in the fractal dimension values obtained when repeating the measurements. In addition, the vast majority of medical images are now digital (such as magnetic resonance imaging), which limits the use of the classical method using a caliper for digital images without pre-printing. These factors cause insufficient accuracy and convenience of this method and limit its use in the medical field for diagnostic purposes.

The modification described in this paper is automated and does not require a lot of time required for manual calculation. In addition, compared to the classical method, this modification is more accurate because the measurement is performed automatically. Changing the fractal measure is not done by changing the length of the fractal segment, as in the classical method, but automatically - by changing the radius of smoothing the contour. This modification of the contour eliminates the influence of subjective factors in the calculation and greatly simplifies the study.

The described technique is a methodologically simple algorithm that does not require additional programs for complex image segmentation and skills in working with these programs. Outline selection and modification is performed using Adobe Photoshop CS5 (or later versions of Adobe Photoshop), which is quite accessible and common in use. In addition to this program, you can use other graphics editors that have options comparable to or better than the version of the graphics editor we used. Thus, it allows to widely use the developed modification of the Caliper method for fractal analysis of linear anatomical structures as a morphometric method in morphology and other fields of medicine for diagnostic purposes.

\section{References}

[1] Akar, E., Kara, S., Akdemir, H., \& Kiris, A. (2015). Fractal dimension analysis of cerebellum in Chiari Malformation type I. Computers in Biology and Medicine, 64, 179-186. doi: 10.1016/ j.compbiomed.2015.06.024

[2] Carey, S. \& Maria, A. \& Sigurdsson, H. (2000). Use of fractal analysis for discriminaion of particles from primary and reworked jokulhlaup deposits in SE Iceland. Journal of Volcanology and Geothermal Research, 104, 65-80. doi: 10.1016/S0377-0273(00)00200-6

[3] Di leva, A., Esteban, F. J., Grizzi, F., Klonowski, W., \& MartinLandrove, M. (2015). Fractals in the neurosciences, Part II: clinical applications and future perspectives. The Neuroscientist: a review journal bringing neurobiology, neurology and psychiatry, 21(1), 30-43. doi: 10.1177/ 1073858413513928

[4] Di leva, A., Grizzi, F., Jelinek, H., Pellionisz, A. J., \& Losa, G. A. (2014). Fractals in the Neurosciences, Part I: General Principles and Basic Neurosciences. The Neuroscientist: a review journal bringing neurobiology, neurology and psychiatry, 20(4), 403-417. doi: 10.1177/1073858413513927

[5] Feder J. (1988) Fractals. New York: Plenum Press, 284.
The main limitation in using the developed modification of the Caliper method is the ability to determine the fractal dimension of only closed contours of certain structures or closed linear structures, as this method involves determining the length of the perimeter of the area highlighted in the image. Therefore, for fractal analysis of open lines, preference should be given to the classical Caliper method or other methods of fractal analysis. In addition, the selection of the linear contour requires high accuracy and visual control of the selected area, which somewhat limits the automation of the calculation, as sometimes requires manual correction (automatic selection graphic editor does not always allow to select the study area accurately and according to anatomical features) and may cause the influence of subjective factors in the selection of the contour, as the correction of the selected area is done manually.

\section{Conclusions}

1. The method of determining the fractal dimension using the author's modification of the Caliper method described in this paper is original and can be used in morphology and other fields of medicine for fractal analysis of linear objects: external and internal linear contours of different anatomical structures (cerebellum, hemispheres of brain) and pathological foci (tumors, foci of necrosis, fibrosis, etc.).

2. The Caliper method should be preferred in the study of linear anatomical objects, as this method takes into account only one linear line size (length), eliminating the effect of line width on fractal dimension values.

3. The original modification of the Caliper method has advantages over the classic Caliper method, because the modification is automated, so it is less routine, takes less time and allows you to get more accurate results.

[6] Fernandez, E, \& Jelinek, H. F. (2001) Use of fractal theory in neuroscience: methods, advantages, and potential problems. Methods, 24(4), 309-321. doi: 10.1006/meth.2001.1201

[7] Jelinek, H. F., \& Fernandez, E. (1998). Neurons and fractals: how reliable and useful are calculations of fractal dimensions? Journal of Neuroscience Methods, 81(1-2), 9-18. doi: 10.1016/ s0165-0270(98)00021-1

[8] King, R. D., Brown, B., Hwang, M., Jeon, T., George, A. T., \& Alzheimer's Disease Neuroimaging Initiative (2010). Fractal dimension analysis of the cortical ribbon in mild Alzheimer's disease. Neurolmage, 53(2), 471-479. doi: 10.1016/ j.neuroimage.2010.06.050

[9] King, R. D., George, A. T., Jeon, T., Hynan, L. S., Youn, T. S., Kennedy, D. N. ... the Alzheimer's Disease Neuroimaging Initiative (2009). Characterization of Atrophic Changes in the Cerebral Cortex Using Fractal Dimensional Analysis. Brain Imaging and Behavior, 3(2), 154-166. doi: 10.1007/s11682008-9057-9

[10] Kiselev, V. G., Hahn, K. R., \& Auer, D. P. (2003). Is the brain cortex a fractal? Neurolmage, 20(3), 1765-1774. doi: 10.1016/ s1053-8119(03)00380-x 
[11] Lee, K. I., Choi, S. C., Park, T. W., \& You, D. S. (1999). Fractal dimension calculated from two types of region of interest. Dento Maxillo Facial Radiology, 28(5), 284-289. doi: 10.1038/ $\mathrm{sj} / \mathrm{dmfr} / 4600458$

[12] Manabe, Y., Honda, E., Shiro, Y., Sakai, K., Kohira, I., Kashihara, K., ... \& Abe, K. (2001). Fractal dimension analysis of static stabilometry in Parkinson's disease and spinocerebellar ataxia. Neurological research, 23(4), 397-404. doi: 10.1179/ 016164101101198613

[13] Mandelbrot, B. B. (1983) The fractal geometry of nature. N.Y.: W. H. Freeman\&Co, 468.

[14] Mandelbrot, B. B. (1967) How Long Is the Coast of Britain? Statistical Self-Similarity and Fractional Dimension. Science, New Series, 3775(156), 636-638.

[15] McLachlan, C. S., Jelinek, H. F., Kummerfeld, S. K., Rummery, N., McLachlan, P. D., Jusuf, P. .... Yin, J. (2000). A method to determine the fractal dimension of the cross-sectional jaggedness of the infarct scar edge. Redox Report: communications in free radical research, 5(2-3), 119-121. doi: $10.1179 / 135100000101535401$

[16] Rajković, N., Krstonošić, B., \& Milošević, N. (2017). BoxCounting Method of 2D Neuronal Image: Method Modification and Quantitative Analysis Demonstrated on Images from the Monkey and Human Brain. Computational and Mathematical Methods in Medicine, 2017, 8967902. doi: 10.1155/2017/
8967902

[17] Ristanović, D., Stefanović, B. D., \& Puskas, N. (2013). Fractal analysis of dendrites morphology using modified Richardson's and box counting method. Theoretical Biology Forum, 106(12), 157-168.

[18] Ristanovi, D., Stefanović, B. D., \& Puškaš, N. (2014). Fractal analysis of dendrite morphology of rotated neuronal pictures: the modified box counting method. Theoretical Biology Forum, 107(1-2), 109-121.

[19] Shrout, M. K., Potter, B. J., \& Hildebolt, C. F. (1997). The effect of image variations on fractal dimension calculations. Oral Surgery, Oral Medicine, Oral Pathology, Oral Radiology, and Endodontics, 84(1), 96-100. doi: 10.1016/s10792104(97)90303-6

[20] Stoa, R. (2020). The Coastline Paradox. Rutgers University Law Review, 72(2), 351-400. doi: 10.2139/ssrn.3445756

[21] Wu, Y. T., Shyu, K. K., Jao, C. W., Wang, Z. Y., Soong, B. W., Wu, H. M., \& Wang, P. S. (2010). Fractal dimension analysis for quantifying cerebellar morphological change of multiple system atrophy of the cerebellar type (MSA-C). Neurolmage, 49(1), 539-551. doi: 10.1016/j.neuroimage.2009.07.042

[22] Zaletel, I., Ristanovi, D., Stefanović, B. D., \& Puškaš, N. (2015). Modified Richardson's method versus the box-counting method in neuroscience. Journal of Neuroscience Methods, 242, 9396. doi: 10.1016/j.jneumeth.2015.01.013

\section{ФРАКТАЛЬНИЙ АНАЛІЗ ЯК МЕТОД МОРФОМЕТРИЧНОГО ДОСЛІДЖЕННЯ ЛІНІЙНИХ АНАТОМІЧНИХ ОБ'ЄКТІВ: AВТОРСЬКА МОДИФІКАЦІЯ СПОСОБУ CALIPER Мар'єнко Н.І., Степаненко О.Ю.}

Мета дослідження - розробка оригінальної модифрікації способу Caliper для визначення фррактальної розмірності лінійних анатомічних об'єктів. Для розробки методики у якості об'єкта дослідження обрано лінійний контур зовнішньої поверхні кори великих півкуль головного мозку. Були використані магнітно-резонансні томограми головного мозку у корональній проекції. Оригінальна модифрікація способу Caliper включає аналіз зображення за допомогою програми Adobe Photoshop CS5 або ї аналогів. Проводиться виділення лінійного контуру досліджуваного об'єкту із наступним поетапним згладжуванням контуру із різним радіусом зеладжування. На 1-му етапі фрактального аналізу зеладжування не застосовується, на 2-му етапі радіус заладжування складає 2 пікселі, 3-му - 4 пікселі, 4-му - 8 пікселів, 5-му - 16 пікселів. На кожному етапі проводиться вимірювання довжини контуру у пікселях (P). Розмір фрактальної міри (G) складає на 1-му етапі фрактального аналізу 1 піксель, на 2-му етапі - 2 пікселі, 3-му - 4 пікселі, 4-му - 8 пікселів, 5-му - 16 пікселів. Радіус зәладжування контуру, розмір фррактальної міри та кількість етапів фррактального аналізу можуть бути змінені у залежності від особливостей досліджуваної структури, розміру, маситабу та роздільної здатності зображення. На основі значень периметра та розміру фррактальної міри розраховують $N$ - кількість фррактальних мір, що покривають досліджуваний об'єкт: N=P/G. Значення фррактальної розмірності розраховується на основі значень N та G. Модифрікація способу Caliper, описана у цій роботі, $\epsilon$ автоматизованою та не потребує великих затрат часу, необхідних для ручного підрахунку. Крім цього, у порівнянні з класичним способом Caliper, ия модифрікація $\epsilon$ більш точною, оскільки вимірювання проводиться автоматизовано. Основним обмеженням у використанні розробленої модифрікації є можливість визначення фррактальної розмірності лише замкнених контурів певних структур або замкнених лінійних структур, оскільки цей спосіб передбачає визначення довжини периметра ділянки, виділеної на зображенні. Методика визначення фррактальної розмірності за допомогою оригінальної модифрікації способу Caliper, описана у даній роботі, може бути використана у морфології та інших галузях медицини для фррактального аналізу лінійних об'єктів: зовнішніх та внутрішніх лінійних контурів різних анатомічних структур (мозочка, великих півкуль головного мозку) та патологічних осередків (пухлин, осередків некрозу, фьброзу тощо).

Ключові слова: фрактальний аналіз, фррактальна розмірність, морфометрія, спосіб Caliper, спосіб Річардсона. 